\title{
The Ethical Demand for Editorial Diversity in a Context of Concentrated Newspaper Ownership in Chile
}

\section{Maria Elena Gronemeyer ${ }^{1}$ William Porath ${ }^{2}$}

We are grateful for the support provided by research assistants Muriel Alarcón, Constanza Carter, Valentina Becker, Esteban Herrera, Francisca Torres, Camila Verdugo, Belén Miranda and Flor Guzmán from the Journalism School at the Pontificia Universidad Católica de Chile.

Recibido: 2013-03-25

Envío a pares: 2013-04-16
Aprobado por pares: 2013-05-29

Aceptado: 2013-06-07

\section{Para citar este artículo / To reference this article / Para citar este artigo}

Gronemeyer, M. E. Marzo de 2014. The Ethical Demand for Editorial Diversity in a Context of Concentrated Newspaper Ownership in Chile. Palabra Clave 17 (1), 71-101.

\section{Abstract}

The focus of this study is on empirical research to determine whether concentrated newspaper ownership in Chile reflects a homogenization of the topics covered in newspaper editorials. The subject areas addressed in the editorials of three national dailies (El Mercurio, La Tercera and La Segunda) and two regional newspapers (El Sur de Concepción and La Discusión de Chillán) during 2005, 2009 and 2011 are examined to arrive at a quantitative measurement of the similarities in editorial topics within and among the newspapers selected as a reference. The study concludes with a correlation analysis to determine the homogeneity - heterogeneity of the topics on the editorial agenda.

\section{Keywords}

Ethics of the press, the press, agenda, Chile (Source: UNESCO Thesaurus). 


\section{La exigencia ética de la diversidad editorial en un contexto de concentración de la propiedad de los periódico en Chile}

\section{Resumen}

Este estudio se propone realizar una investigación empírica para determinar si la concentración de la propiedad de la prensa chilena se refleja en una homogeneización de los temas tratados en los editoriales de los periódicos. La investigación estudia las áreas temáticas tratadas en los editoriales de tres diarios de referencia nacionales (El Mercurio, La Segunda y La Tercera) y dos periódicos regionales (El Sur de Concepción y La Discusión de Chillán) durante 2005, 2009 y 2011 para medir cuantitativamente las coincidencias en los temas editorializados entre y dentro de ellos. Se concluye con un análisis con correlaciones para determinar la homogeneidad - heterogeneidad de las pautas o agendas de temas editorializados.

\section{Palabras clave}

Ética de la prensa, prensa, agenda, Chile. (Fuente: Tesauro de la UNESCO). 


\section{A exigência ética da diversidade editorial num contexto de concentração da propriedade dos jornais no Chile}

\section{Resumo}

Este estudo se propõe realizar uma pesquisa empírica para determinar se a concentração da propriedade da imprensa chilena se reflete em uma homogeneização dos temas tratados nos editoriais dos jornais. Esta pesquisa estuda as áreas temáticas tratadas nos editoriais de três jornais de referência nacionais (El Mercurio, La Segunda e La Tercera) e dois jornais regionais (El Sur de Concepción e La Discusión de Chillán) durante 2005, 2009 e 2011 para medir quantitativamente as coincidências nos temas editorializados entre e dentro deles. Conclui-se com uma análise com correlações para determinar a homogeneidade-heterogeneidade das pautas ou agendas de temas editorializados.

\section{Palavras-chave}

Ética da imprensa, imprensa, agenda, Chile. (Fonte: Tesauro da UNESCO). 


\section{Introduction}

As of the mid-1980s, the global trend toward growing concentration in media ownership has begun to raise ethical concerns from a mass communication perspective about diminishing numbers of media outlets and decreasing diversity in points of view. Given the impact of this trend on pluralism and democracy, various studies have tested the hypothesis that concentrated media ownership contributes to the homogenization of editorial positions and content.

In Chile, concentration of media ownership, and especially of newspapers, has been a recurring topic in academic debate. Most authors contend this trend has resulted in homogenization of content and an ideological monopoly that seriously affects pluralism and access to all representative voices and groups in Chilean society. This thesis has been supported mainly by research on the structure of media companies, including ownership, investment, advertising and readership.

This study provides quantitative data to determine whether concentration of ownership in the Chilean press has resulted in the homogenization of topics addressed in editorial spaces, supporting the view of the media as an ideological monopoly. ${ }^{3}$ Based on the discussion of diversity raised by McQuail (1998), this study distinguishes inter-media homogeneity from intra-media homogeneity.

The investigation ${ }^{4}$ applied content analysis to a sample of 2,343 editorials published in three national newspapers and two regional newspapers during March, July and November of 2005, 2009 and 2011 to quantitatively determine the degree of thematic overlap within and among the five newspapers.

\footnotetext{
3 This article reports on the first part of a three-year project. Partial results were presented during an academic workshop at the Research Center on Media and Communication at the Universität Hamburg, Germany, in 2012, and at the IAMCR annual conference in Dublin in 2013. Therefore, the theoretical and methodological framework might not contain major variations, but this is the first time the empirical results of this research are published in English.

4 This project is funded by the National Fund for Scientific and Technological Development of Chile FONDECYT (Project No. 1110306).
} 
The newspapers analyzed include Chile's two most important national newspapers: El Mercurio (owned by El Mercurio SAP) and La Tercera (owned by Copesa SA), both of which are published in Santiago. The parent firms; that is, El Mercurio SAP and Copesa SA constitute Chile's newspaper duopoly. The third newspaper, La Segunda, published in Santiago, is an evening paper also owned by El Mercurio SAP.

Additionally, the study reviewed two regional newspapers: El Sur de Concepcion (which changed ownership during the period covered by this study, when it was purchased by El Mercurio SAP), and the independent newspaper La Discusión de Chillán.

This research also tracked changes in the topics selected for the editorials by these two media enterprises following the election of President Sebastián Piñera, during the final segment of the period under review. This duopoly has been accused of favoring concerns and projects that are part of the government agenda from 2010 onward, for the first time since the military government (up to 1990).

\section{Theoretical framework}

The trend toward uniformity in editorial topics covered by mainstream newspapers is a relevant subject of academic and professional discussion, given that these newspapers are viewed as having an ethical responsibility to inform about the debate on matters of public interest. The trend is criticized for its negative impact on the promotion of critical thinking on two fronts: the media's public service role, and development and consolidation of democracy. The origin of this trend is attributed to multiple causes: liberalization of media regulations (L. George, 2007; Freedman, 2005; Llorens, 2003); growing concentration of ownership of media companies (Carpentier, 2007; Horwitz, 2005); and understanding the news media as for-profit companies (Glasser, 2005). In their discussion of news and inclusion, Glasser and Awad (2010) stress that: "To be sure, the diversification of journalism promises more than a heightened sensitivity to cultural differences. It broadens the base of journalism by creating an infrastructu- 
re for debates and discussions of the kind that market-driven journalism seldom accommodates."

Given the ethical challenges for journalism and its social implications, this issue should be analyzed from the dual perspectives of inter- and intramedia diversity (McQuail, 1998). Van Cuilenburg (2002) highlights the importance of both dimensions to the diversity debate. Whereas intra-media diversity means ensuring audiences are confronted with diverse issues, ideas and opinions, inter-media diversity is of greater importance for the individual reader because, according to Van Cuilenburg (2002), it allows the reader to satisfy individual preferences by choosing between products with different editorial content. Thematic diversity within and among media is complementary and is addressed by this study.

Critical discussion of the phenomenon of homogeneity is important because it reflects the undisputed ability of media to shape public opinion and citizen behavior. The discussion involves the concept of information enterprises as providers of a public service, bound by professional requirements and ethical standards to produce media content to satisfy audience expectations and needs (Sánchez-Tabernero, 2006; Cortina, 2004).

\section{The Contribution of Editorial Content to Public Debate}

The perception that diversity of editorial content is shrinking is a matter of concern in democratic systems. The studies reviewed are inconclusive about the reasons for this trend. Research suggests several influences, including professional routines and similar worldviews among media enterprise owners, managers and advertisers, besides concentration of media ownership and limited availability of media (Villamil, 2009; Murciano, 2006). ${ }^{5}$

Researchers agree on the negative impacts of a media system that is incapable of serving the democratic goals of informed citizenship, delibe-

5 The topic is also discussed by E. George (2007), Carpentier (2007), Ho \& Quinn (2009), Horwitz (2005, 2003), among other authors. 
ration and the exercise of public control. Ettema (2007) says that, as a rational institution, journalism must contribute to deliberative democracy, which Gutmann and Thompson (2004) define as "a form of government in which free and equal citizens (and their representatives) justify decisions in a process where they give one another reasons that are mutually acceptable and generally accessible, with the aim of reaching conclusions that are binding in the present on all citizens but open to challenge in the future" (p.7). According to Gutmann and Thompson (2004), this implies the media also must enrich public debate by registering deliberative processes and participating in them. Lasch (1995) asserts that simple delivery of data is insufficient; what matters is citizen empowerment through critical and constructive debate, freedom and self-government. Schudson (1995) adds that the purpose of media is to help citizens obtain an "adequate understanding" of their context, including political preferences and the moral and value choices at stake.

Stevenson (2002) cites McLuhan to highlight media as modern devices for the dissemination of cultural forms and social influence. Several authors discuss the media's capacity to influence social values and community beliefs, attitudes and aspirations through the ideas, opinions and attitudes they provide for public debate (Fuenzalida, 2005, Bandura, 1986). As Christiane Eilders (2000) states: "Media not only act as neutral information agencies providing a forum for other actors. They take an active role in the political process by selecting and structuring information, assigning relevance, interpreting and evaluating the stream of events continuously taking place" (p.182).

Editorials (defined here as the unsigned texts published in spaces dedicated to opinion that represent the position of the media itself) facilitate awareness, reflection and analysis of current affairs from a particular stance or point of view (Blanks, 2008; Ho \& Quinn, 2009). According to González (1991), the editorialist has the opportunity to explain the meaning of the news and thus influence public opinion. The editorialist interprets, examines, contextualizes and judges key events. Filippi (1997) attributes to editorials the capacity to influence social behavior, modify government 
decisions, and strengthen (or discredit) political institutions. As González (2005) states: "The editorial is the discourse of the press par excellence, since it openly expresses the interest of the media enterprise to participate in the organization of public space and its ideological positions regarding the socio-political contingency" (p.525). Eilders (2000) adds: "Focusing on editorials, the notion of media competition gains special significance, since editorials provide an easy means to communicate an outlet's particular view and address the corresponding segments of the audience. It can be assumed that differences between media outlets show most clearly in the opinion sections" (p.184).

Horwitz (2005) highlights the open clash of issues and differing viewpoints as a prerequisite of democracy, and that diversity of editorial content and unrestricted exchange of diverse ideas guarantees optimal decision-making and the building of public policy. Socorro Apreza (2005) agrees that "openness to the various schools of thought and ideas ensures citizens the possibility to evaluate different and even contradictory ideological views" (p.63).

Therefore, diversity in editorials should be guaranteed through the existence of multiple media representing different worldviews on diverse topics, observing and assessing reality from diverse angles (McQuail, 1998, Van Cuilenburg, 2002). As suggested by Meg Sullivan (2005), a near-perfect balance of differing perspectives on an issue is achieved if the audience is exposed to a range of different media for the same amount of time.

According to Chilean researchers Sunkel and Geoffroy (2001), these guarantees are absent in Chile due to the existence of an "ideological monopoly" in the national press rooted in the ideological uniformity of local media managers who adhere to the neo-liberal economic model and conservative values. This monopoly, they contend, has a double impact on the media, as seen in its editorial line and journalistic content, both of which are limited by self-censorship so as not to upset those who provide financial resources to the media. According to this thesis, El Mercurio has been characterized repeatedly as the disseminator of the political-economic beliefs of the Chilean right (Soto, 2003; Sunkel, 1986). 


\section{Empirical Evidence}

In addition to content analysis (quantifying and registering quotes, political statements, the time and space given to candidates and columnists, topics covered and specific texts), numerous surveys have been applied to citizens and editors to identify topics, positions and practices.

Several studies have sought to determine whether concentration of media ownership leads to homogeneity of editorial and news content and reduces pluralism. Ho and Quinn (2009) and Elke Grittmann (2009) are some examples. ${ }^{6}$ However, their findings have been inconclusive.

Other research has focused on the laws governing the media ownership that would undermine media pluralism, as conducted by Apreza (2005), in Spain, and E. George (2007) in Canada. In Germany, Elke Grittmann (2009) did content analysis on the quality and diversity of journalistic outputs in six regional papers and found diversity loss due to media mergers and a general decline in overall newspaper quality.

Elizabeth Blanks (2008) studied editorial content, making a methodological contribution to this discussion through the use of "ethnographic content analysis" (based on Altheide), which is a qualitative method that involves applying general categories to texts while also allowing for the emergence of new categories.

In Chile, research on media structure has looked at ownership, investment, advertising and readership. Studies have addressed bias and homogeneity in the Chilean press as outcomes of ideological and economic concentration, introducing the concepts of media monopoly, duopoly or oligopoly to describe the country's media landscape. In this view, ideological monopoly is a product of concentrated media ownership and a similar concentration of ideas and values among owners and advertisers (Sunkel and Geoffroy, 2001; Del Valle, 2004).7 Olivia Mönckeberg (2009) echoes

6 A number of additional authors were reviewed, such as Horwitz (2005), Woods (2007) and Rennhoff and Wilbur (2011).

7 Additional relevant research has been done by investigators such as Portales (1999), Dermota (2002), Krohne (2002, 2005), Mönckeberg (2009) and Corrales y Sandoval (2004). 
the concerns of those who believe the situation is deteriorating when she states that: "few countries in the world are so extreme, with diversity totally absent from the press and extremely limited in TV" (p.13).

The few studies that have analyzed media pluralism and media content homogeneity have limited their research to news stories, and have excluded editorials from their analysis, including studies by Valenzuela and Arriagada (2009). Porath (2000; 2000b) researched ideological monopoly by examining headlines in Chilean newspapers during the 1999 Presidential campaign and found that most headlines were damaging to Concertación candidate Ricardo Lagos, a socialist. Studies of the 2005 electoral campaign reviewed TV news content (Porath, 2007; Porath, 2007b), where only some media repeated this tendency. Santander (2007) analyzed news content between 2002 and 2005 and concluded that, while the media adopted some watchdog functions, the predominant trend was the popularization of a journalistic style that transformed news into drama and spectacle. One Chilean study looks at editorials from a semiotic perspective (González, 2005), providing an initial description of editorial content and the intentions attributed to them.

\section{Hypotheses}

Based on the discussion in the theoretical framework, this study proposes the following two hypotheses and respective research questions.

H. 1. A significant and sustained concentration of editorial topics during the period analyzed can be found among the three Chilean newspapers (El Mercurio, La Tercera and La Segunda) most regarded as platforms for public debate, with the greatest influence on public opinion and the national media agenda.

Question 1. Is the same concentration found in the two regional newspapers included in this study (El Sur de Concepción and La Discusión de Chillán)?

Question 2. Are there significant differences in the topics discussed in the media over the three years covered by this study? 
H. 2. A significant and sustained overlap in editorial topics covered during the period analyzed can be found among the three Chilean newspapers (El Mercurio, La Tercera and La Segunda) most regarded as platforms for public debate, with the greatest influence on public opinion and the national media agenda.

Question 1. Is the same overlap found between the two regional newspapers included in this study (El Sur de Concepción and La Discusión de Chillán) and the Santiago-based newspapers?

Question 2. After ownership of El Sur de Concepción changed in 2006, did the overlap increase between the topics covered by its editorials and those of newspapers belonging to El Mercurio SAP? (In other words, following its acquisition by El Mercurio SAP, did the editorial topics of El Sur de Concepción show a greater resemblance to the editorials themes in El Mercurio and La Segunda than to editorial topics in La Discusión de Chillán?)

Question 3. Did the topics of editorials covered by these five newspapers change when President Sebastián Piñera took office in March 2010?

\section{Methodology}

This study aims to empirically determine the degree of homogeneity of the editorial topics addressed in five major newspapers, looking at the choice of subject matter as a measure of reduced intra- and inter-media pluralism or diversity. It constitutes the first phase of a three-part research project. The second part will examine the degree of homogeneity among the opinions expressed in the editorials on specific issues within a topic; the third will examine whether this potential homogeneity is also replicated in news stories.

Content analysis was applied to nine months of editorials, published over a three-year period, in five Chilean newspapers. Systematic analysis of media content to describe and evaluate media outputs is an established and valued methodology of communication researchers (Neuendorf, 2002). The method allows for the collection of quantitative data from publiclyavailable material using replicable procedures. 


\section{Newspapers Reviewed}

The five media selected as units of analysis were: El Mercurio (EM), La Tercera (LT), La Segunda (LS), La Discusión de Chillán (LD) and El Sur de Concepción (ES). El Mercurio and La Tercera are the main national newspapers published by Chile's two largest print media companies: El Mercurio SAP and Copesa SA. Together, and due to the influence of their editorial and information spaces, they are said to constitute an ideological duopoly. La Segunda, an evening newspaper also owned by El Mercurio SAP, is also a newspaper of reference, especially in the political arena. Its inclusion allowed for comparisons between newspapers of the same enterprise. Copesa SA has no equivalent newspaper.

Two regional newspapers were included in the sample. El Sur de Concepción was added for its long history and importance as the newspaper of record in southern Chile. After a century in the hands of the Radical Party and then the Lamas family, El Sur de Concepción was purchased in 2006 by El Mercurio SAP. The acquisition of that paper by El Mercurio SAP has increased the company's network of regional newspapers and the extension of its alleged ideological monopoly to the rest of the country. The inclusion of El Sur de Concepción in this study allows for comparisons before and after its change in ownership and eliminates the need to include another regional paper owned by El Mercurio SAP. That role will be filled by El Sur de Concepción subsequent to its sale.

The newspaper La Discusión de Chillán has a 140-year history and is independent of El Mercurio SAP and Copesa SA. It is used in this study as a "control variable" (content of a media not belonging to the duopoly). The similarities between La Discusión de Chillán and El Sur de Concepción as media of record allow for the comparison to El Sur de Concepción before and after its acquisition by El Mercurio SAP.

\section{Editorial Samples}

The editorials sampled were published during the months of March, July and November in the years 2005, 2009 and 2011. This period was long enough to detect trends and include a year concurrent with the development of the 
study (2011). Use of an extended period and a sufficient volume of cases avoided the possibility of attributing similarities to circumstances or statistical probability, as noted by González (2005).

The study collected editorial samples via Internet, using Nextchannel SA software for material published as of 2009, and via microfilm versions stored in Chile's National Library for papers from 2005. A total of 2,343 editorials were collected.

In terms of the amount and frequency of editorials, El Mercurio published the greatest number, with an average of four daily (Monday through Sunday). La Tercera published one editorial daily (Monday through Sunday), increasing to two per day in 2011. La Segunda published an average of 1.5 editorials daily from Monday through Friday (the paper is not published on weekends). La Discusión de Chillán published an average of 1.8 editorials daily (Monday through Sunday). El Sur de Concepción published an average of 1.3 editorials daily, also Monday through Sunday. This distribution is shown in Table 1 .

\section{Table 1: Editorial samples from five newspapers}

\begin{tabular}{|c|c|c|c|c|}
\hline Newspapers & 2005 & 2009 & 2011 & Total \\
\hline El Mercurio & 316 & 330 & 334 & 980 \\
\hline La Tercera & 92 & 92 & 182 & 366 \\
\hline La Segunda & 64 & 105 & 95 & 264 \\
\hline La Discusión & 93 & 151 & 184 & 428 \\
\hline El Sur & 123 & 90 & 92 & 305 \\
\hline Total & 688 & 768 & 887 & 2,343 \\
\hline
\end{tabular}

The table was constructed from a list of main topics and subtopics to classify and code for each editorial, accompanied by a classification sheet and codebook with application criteria and an "issue within the topic" descriptive variable. Inclusion of the latter variable takes into account the pos- 
sibility that, when referring to a specific news event, the editorialized issue differed from the topic. Different editorials may address the same topic, but focus on diverse issues within it. In the second phase of this study, coders will need to be able to decide if two or more newspapers were editorializing on the same issues.

These instruments were tested several times with eight research assistants, and the resulting adjustments were made to codebook and topics list. Once finalized, the procedure allowed us to limit the corpus of editorials to those dealing with topics of national public interest. The list includes 41 categories divided into 10 sections. The categorized editorials were then recoded into 14 categories: "government and public institutions," "regional and local government," "legislation," "national defense and foreign policy," "politicians and parties," "campaigns and elections," "economy, finance and business," "labor, unions and consumers," "transport, environment and energy," "education," "justice and police," "health, housing and social policies," "culture, society and others," and "international policy."

Three coders were trained to classify the full sample, alternating the five newspapers to minimize possible distortions from potential misclassification. Using multiple coders, Cohen's kappa was employed to measure inter-coder reliability. (Cohen's kappa is a coefficient that accounts for agreement occurring by chance. Scores ranging from 0.61 to 0.80 designate substantial agreement [Viera and Garrett, 2005]). Our reliability test registered an average agreement of 0.67 based on $12.8 \%$ of the total sample (300 editorials) reclassified by the three trained coders. The coded topics were entered in a SPSS database to conduct inter- and intra-media frequency analyses of topic diversity for the objectives of this study.

\section{Findings \\ Intra-Media Homogeneity}

To measure the homogeneity/ heterogeneity of editorial topics, we used Shannon's H entropy index as an indicator of diversity. We recoded the 41 codes of the variable "topic" into 14 major subject areas and analyzed multiple responses based on the total number of editorialized items in order to obtain fractions totaling 100\%, (a requirement for the calculation of entropy). 
The values for year 2005 (see Table 2) indicate that, of the three Santiago-based newspapers, El Mercurio shows the greatest range of topics. $\mathrm{La}$ Segunda and La Tercera demonstrate a higher degree of concentration. This could be related to the number of editorials published daily in these newspapers. As regards the regional newspapers (La Discusión de Chillán and $E l$ Sur de Concepción), both register a range of topic diversity similar to that of El Mercurio. In contrast, La Discusión de Chillán has the same number of editorials as $L a$ Tercera, but registers substantially higher entropy, exceeding that of El Sur de Concepción, which has a third more editorials.

According to the statistical analysis, the readership of Santiago-based national newspapers in 2005 did not find a wider range of editorial topics than that offered by El Mercurio.

\section{Table 2: Percentage of topic diversity in five Chilean newspapers, 2005}

\begin{tabular}{|l|c|c|c|c|c|c|c|}
\hline $\begin{array}{l}\text { Topics (up to 3 mentions) } \\
2005 \text { (3 months) }\end{array}$ & $\begin{array}{c}\text { El } \\
\text { Mercurio }\end{array}$ & $\begin{array}{c}\text { La } \\
\text { Tercera }\end{array}$ & $\begin{array}{c}\text { La } \\
\text { Segunda }\end{array}$ & $\begin{array}{c}\text { La } \\
\text { Discusión }\end{array}$ & El Sur & $\begin{array}{c}\text { Total } \\
\text { average }\end{array}$ & $\begin{array}{c}\text { Average } \\
\text { Santiago }\end{array}$ \\
\hline $\begin{array}{l}\text { Government and public } \\
\text { bodies }\end{array}$ & 15,9 & 14,0 & 13,6 & 6,7 & 12,4 & 12,5 & 14,5 \\
\hline $\begin{array}{l}\text { Economics, Finance and } \\
\text { Business }\end{array}$ & 18,1 & 9,5 & 7,2 & 10,3 & 7,4 & 10,5 & 11,6 \\
\hline Justice and Police & 9,7 & 11,7 & 12,8 & 9,2 & 15,5 & 11,8 & 11,4 \\
\hline $\begin{array}{l}\text { Culture, Society and } \\
\text { others }\end{array}$ & 3,4 & 7,3 & 7,2 & 19,0 & 6,2 & 8,6 & 5,9 \\
\hline Education & 5,9 & 3,4 & 5,6 & 5,1 & 4,7 & 4,9 & 4,9 \\
\hline Politicians and Parties & 6,2 & 5,6 & 15,2 & 1,5 & 8,5 & 7,4 & 9,0 \\
\hline Campaignsand Elections & 6,2 & 9,5 & 14,4 & 3,6 & 13,6 & 9,5 & 10,0 \\
\hline International Policy & 10,4 & 17,3 & 5,6 & 5,1 & 3,9 & 8,5 & 11,1 \\
\hline Legislation & 7,0 & 9,5 & 4,0 & 2,6 & 0,4 & 4,7 & 6,8 \\
\hline $\begin{array}{l}\text { Transport, Environment } \\
\text { and Energy }\end{array}$ & 4,0 & 1,1 & 2,4 & 10,3 & 5,0 & 4,6 & 2,5 \\
\hline $\begin{array}{l}\text { Health, Housing, Social } \\
\text { Policies }\end{array}$ & 3,7 & 1,7 & 0,0 & 8,2 & 3,9 & 3,5 & 1,8 \\
\hline $\begin{array}{l}\text { National Defense and } \\
\text { Foreign Policy }\end{array}$ & 6,0 & 8,4 & 11,2 & 4,1 & 12,0 & 8,3 & 8,5 \\
\hline $\begin{array}{l}\text { Regional and Local } \\
\text { Government }\end{array}$ & 0,5 & 0,0 & 0,8 & 9,7 & 5,0 & 3,2 & 0,4 \\
\hline $\begin{array}{l}\text { Labor, Unions and } \\
\text { Consumers }\end{array}$ & 2,9 & 1,1 & 0,0 & 4,6 & 1,6 & 2,0 & 1,3 \\
\hline $\begin{array}{l}\text { Counting number of } \\
\text { topics }\end{array}$ & 596 & 179 & 125 & 195 & 258 & 1353 & 900 \\
\hline N (editorials) & 316 & 92 & 64 & 93 & 123 & 688 & 472 \\
\hline Entropy & 0,92 & 0,89 & 0,87 & 0,94 & 0,92 & 0,96 & 0,92 \\
\hline
\end{tabular}


Overall, the thematic diversity of editorials remained largely unchanged in 2009 (see Table 3). However, significant changes can be observed in two newspapers. Both La Segunda and La Discusión de Chillán register a notable decrease in diversity, despite the fact that both newspapers increased the number of editorials during this period. At the same time, El Sur de Concepción reduced the number of editorials per issue, while maintaining its entropy index. In summary, the degree of thematic diversity is not determined by the number of editorials published daily, and is more likely based on editorial policy.

The trend noted in La Discusión de Chillán indicates the range of thematic diversity is unrelated to the newspaper's geographic location. In both Santiago and the regions, examples of low and high concentration of topics exist.

\section{Table 3: Percentage of topic diversity in five Chilean newspapers, 2009}

\begin{tabular}{|c|c|c|c|c|c|c|c|}
\hline $\begin{array}{l}\text { Topics (up to } 3 \text { mentions) } \\
2005 \text { (3 months) }\end{array}$ & $\begin{array}{c}\text { El } \\
\text { Mercurio }\end{array}$ & $\begin{array}{c}\text { La } \\
\text { Tercera }\end{array}$ & $\begin{array}{c}\text { La } \\
\text { Segunda }\end{array}$ & $\begin{array}{c}\text { La } \\
\text { Discusión }\end{array}$ & El Sur & $\begin{array}{c}\text { Total } \\
\text { average }\end{array}$ & $\begin{array}{l}\text { Average } \\
\text { Santiago }\end{array}$ \\
\hline $\begin{array}{l}\text { Government and public } \\
\text { bodies }\end{array}$ & 14,8 & 21,3 & 15,0 & 6,8 & 10,6 & 13,7 & 17,0 \\
\hline $\begin{array}{l}\text { Economics, Finance and } \\
\text { Business }\end{array}$ & 13,7 & 10,4 & 4,8 & 12,6 & 13,9 & 11,1 & 9,6 \\
\hline Justice and Police & 9,9 & 8,1 & 8,7 & 6,8 & 8,3 & 8,4 & 8,9 \\
\hline $\begin{array}{l}\text { Culture, Society and } \\
\text { others }\end{array}$ & 6,4 & 5,2 & 2,4 & 16,7 & 11,1 & 8,4 & 4,7 \\
\hline Education & 5,2 & 6,6 & 3,9 & 3,7 & 12,2 & 6,3 & 5,2 \\
\hline Politicians and Parties & 5,0 & 5,7 & 15,0 & 2,0 & 0,6 & 5,7 & 8,6 \\
\hline Campaignsand Elections & 7,5 & 7,6 & 22,7 & 6,1 & 4,4 & 9,7 & 12,6 \\
\hline International Policy & 9,9 & 6,6 & 7,7 & 0,7 & 4,4 & 5,9 & 8,1 \\
\hline Legislation & 7,2 & 8,1 & 8,2 & 0,7 & 3,3 & 5,5 & 7,8 \\
\hline $\begin{array}{l}\text { Transport, Environment } \\
\text { and Energy }\end{array}$ & 4,6 & 5,2 & 1,9 & 8,5 & 7,2 & 5,5 & 3,9 \\
\hline $\begin{array}{l}\text { Health, Housing, Social } \\
\text { Policies }\end{array}$ & 3,6 & 4,7 & 2,4 & 14,6 & 6,1 & 6,3 & 3,6 \\
\hline $\begin{array}{l}\text { National Defense and } \\
\text { Foreign Policy }\end{array}$ & 5,7 & 5,2 & 4,8 & 1,0 & 3,9 & 4,1 & 5,2 \\
\hline $\begin{array}{l}\text { Regional and Local } \\
\text { Government }\end{array}$ & 2,1 & 1,4 & 0,5 & 18,4 & 6,7 & 5,8 & 1,3 \\
\hline $\begin{array}{l}\text { Labor, Unions and } \\
\text { Consumers }\end{array}$ & 4,4 & 3,8 & 1,9 & 1,4 & 7,2 & 3,7 & 3,4 \\
\hline $\begin{array}{l}\text { Counting number of } \\
\text { topics }\end{array}$ & 614 & 211 & 207 & 294 & 180 & 1506 & 1032 \\
\hline $\mathrm{N}$ (editorials) & 330 & 92 & 105 & 151 & 90 & 768 & 527 \\
\hline Entropy & 0,95 & 0,86 & 0,73 & 0,86 & 0,95 & 0,98 & 0,94 \\
\hline
\end{tabular}


The year 2011 is the only non-election year reviewed in this study, and was included to examine whether the electoral context had an impact on the degree of thematic concentration. No drastic changes are observed (see Table 4). While La Segunda increases slightly the diversity of its editorial topics, it still registers the lowest degree of diversity among the three national newspapers. La Discusión de Chillán increases in diversity, while in El Sur de Concepción decreases. In neither instance is this decrease significant, as was the case with La Discusión de Chillán between 2005 and 2009. The case of La Tercera is interesting in that, in 2011, it doubled the number of its editorials but its thematic diversity remained low.

This appears to indicate the thematic diversity of newspaper editorials is due more to predefined newspaper policies than to circumstances. While the news context may have a short-term impact, it does not appear to have a significant effect on the comparative degree of diversity over time.

As regards thematic concentration in the editorials reviewed, a variable pattern can be detected. El Mercurio has followed a policy of addressing a wider range of topics in its editorials. La Tercera concentrates its editorials on fewer subjects, despite having increased the number of its editorials per paper. La Segunda (with circulation rates equivalent to those of daily newspapers published in a regional capital) is the newspaper with the highest concentration of editorial subject matter. The regional newspapers $L a$ Discusión de Chillán and El Sur de Concepción show greater variability from year to year, and tend to be more diverse than La Tercera.

\section{Thematic Concentration in Three National Newspapers}

Similarities and differences in editorial topic diversity can be observed for the three Santiago-based newspapers during the three years studied and over time.

\section{El Mercurio}

As shown in the tables above, El Mercurio gives "economy, finance and business" a higher priority than do the other national media throughout the period studied. In 2005, editorials in this category significantly surpassed 


\section{Table 4: Percentage of topic diversity in five Chilean newspapers, 2011}

\begin{tabular}{|c|c|c|c|c|c|c|c|}
\hline $\begin{array}{l}\text { Topics (up to } 3 \text { mentions) } \\
2005 \text { ( } 3 \text { months) }\end{array}$ & $\begin{array}{c}\text { El } \\
\text { Mercurio }\end{array}$ & $\begin{array}{c}\text { La } \\
\text { Tercera }\end{array}$ & $\begin{array}{c}\text { La } \\
\text { Segunda }\end{array}$ & $\begin{array}{c}\text { La } \\
\text { Discusión }\end{array}$ & El Sur & $\begin{array}{c}\text { Total } \\
\text { average }\end{array}$ & $\begin{array}{l}\text { Average } \\
\text { Santiago }\end{array}$ \\
\hline $\begin{array}{l}\text { Government and public } \\
\text { bodies }\end{array}$ & 18,7 & 26,8 & 21,4 & 12,1 & 20,6 & 19,9 & 22,3 \\
\hline $\begin{array}{l}\text { Economics, Finance and } \\
\text { Business }\end{array}$ & 11,5 & 5,0 & 4,5 & 8,8 & 10,8 & 8,1 & 7,0 \\
\hline Justice and Police & 10,7 & 10,3 & 7,0 & 4,4 & 7,7 & 8,0 & 9,3 \\
\hline $\begin{array}{l}\text { Culture, Society and } \\
\text { others }\end{array}$ & 8,4 & 7,1 & 4,5 & 15,0 & 5,7 & 8,1 & 6,7 \\
\hline Education & 10,3 & 8,7 & 14,4 & 7,4 & 15,5 & 11,3 & 11,2 \\
\hline Politicians and Parties & 4,0 & 4,5 & 19,9 & 4,4 & 3,1 & 7,2 & 9,5 \\
\hline Campaignsand Elections & 0,6 & 0,3 & 2,0 & 1,5 & 1,0 & 1,1 & 1,0 \\
\hline International Policy & 9,0 & 5,8 & 7,0 & 0,3 & 0,5 & 4,5 & 7,3 \\
\hline Legislation & 6,8 & 10,0 & 10,4 & 3,2 & 4,1 & 6,9 & 9,1 \\
\hline $\begin{array}{l}\text { Transport, Environment } \\
\text { and Energy }\end{array}$ & 6,1 & 5,5 & 0,5 & 10,9 & 8,8 & 6,4 & 4,1 \\
\hline $\begin{array}{l}\text { Health, Housing, Social } \\
\text { Policies }\end{array}$ & 4,2 & 5,5 & 0,5 & 11,8 & 9,3 & 6,3 & 3,4 \\
\hline $\begin{array}{l}\text { National Defense and } \\
\text { Foreign Policy }\end{array}$ & 2,6 & 3,2 & 3,0 & 0,3 & 1,0 & 2,0 & 2,9 \\
\hline $\begin{array}{l}\text { Regional and Local } \\
\text { Government }\end{array}$ & 2,4 & 2,4 & 2,0 & 11,5 & 5,2 & 4,7 & 2,3 \\
\hline $\begin{array}{l}\text { Labor, Unions and } \\
\text { Consumers }\end{array}$ & 4,5 & 5,0 & 3,0 & 8,3 & 6,7 & 5,5 & 4,2 \\
\hline $\begin{array}{l}\text { Counting number of } \\
\text { topics }\end{array}$ & 619 & 380 & 201 & 339 & 194 & 1733 & 1200 \\
\hline $\mathrm{N}$ (editorials) & 334 & 182 & 95 & 184 & 92 & 887 & 611 \\
\hline Entropy & 0,92 & 0,86 & 0,80 & 0,90 & 0,89 & 0,94 & 0,91 \\
\hline
\end{tabular}

those on "government and public institutions." However, the number of editorials on economic topics declined in 2009 and 2011. Especially in 2011, a shift in the thematic priorities of El Mercurio from "economy, finance and business" to "government and public institutions" can be noted, and is also noted in the two other national newspapers. Topics addressing social concerns (for example, "education" and "justice and police") increase in priority in El Mercurio during 2011, a reflection of the student unrest and crime rates reported in the news.

Another relevant aspect of editorial analysis is to look at the topics that appear the least in El Mercurio. These are "regional and local government" and "labor, unions and consumers." This illustrates the paper's policy of focusing on central government to the detriment of discussion of regio- 
nal and local affairs. It also suggests an apparent lack of interest in editorializing on the impacts of trade and economics on ordinary people, although the frequency of this topic did increase in 2009 and 2011. This contrasts with the considerable space permanently dedicated to the managers of the country's economic and financial power.

\section{La Tercera}

While all the Santiago-based newspapers devoted a significant number of their editorials to the topic of "government and public institutions," La Tercera clearly gave priority to this topic, which increased in frequency over the three years of this study to represent $26.8 \%$ of its total editorials in 2011 . The high degree of concentration in its editorial agenda is especially apparent when the degree of treatment of other editorial topics is taken into account. The second ranking topic in La Tercera editorials was "justice and police;" in 2009, "economy, finance and business" increased in visibility; and in 2011, "legislation." As regards the topics least discussed in newspaper editorials over the period studied, La Tercera mirrored the tendency already noted in El Mercurio, giving low priority in its editorials to "regional and local government" and "labor, unions and consumers."

\section{La Segunda}

The editorial agenda of the evening paper La Segunda denotes a newspaper specializing in politics. The paper is characterized by its interest in this area, as reflected in the fact that its editorials focused on "politicians and political parties" over the three years studied. In 2005 and 2009 (both election years), this focus expanded to include "campaigns and elections." These categories appeared twice as often in La Segunda as they did in El Mercurio and La Tercera. During 2011, La Segunda increased its editorial attention to "education" (as did El Mercurio), in response to the frequency of student protests.

\section{Thematic Concentration in Two Regional Newspapers}

A daily paper published for regional distribution in the provincial capital of Concepción, El Sur de Concepción aspires to be the newspaper of record 
for that region. In contrast, La Discusión de Chillán is a newspaper responding to the needs and demands of its local community.

\section{La Discusión de Chillán}

Statistical analysis demonstrates the greater thematic diversity of this Chillán newspaper compared to the other newspapers sampled. Its editorials tend to address topics ignored by Santiago-based media, as demonstrated by its interest in regional and local government. It also gives significant space to social topics such as "culture and society," "transport, environment and energy" and "health, housing and social policies." The category "politics and politicians" is the area least frequently addressed by this newspaper.

\section{El Sur de Concepción}

Greater thematic diversity is also seen in this newspaper, although its editorials tend to coincide more with those of the Santiago-based newspapers. The paper dedicated significant editorial attention to the topic of central government in 2009 and 2011, in addition to "economy, finance and business." As previously noted, this newspaper was acquired by El Mercurio SAP in 2010. Like the Santiago-based press, El Sur de Concepción also focused on the topic of "education" in 2009 and 2011, reflecting the presence of the local Universidad de Concepción in student unrest.

\section{Inter-Media Homogeneity}

Using the tables above, we applied Spearman's correlation index to measure the similarity (homogeneity) of the agendas adopted by the editorial pages of the media outlets studied. Taken from the literature of McCombs and Shaw (1972) and McCombs (2005), the concept of agenda refers to the order of priorities that media (or other actors) use to attribute greater or lesser prominence to topics covered and published. Traditionally, this paradigm uses Spaerman's Rho to evaluate the priorities afforded to topics, rather than the amount of space assigned to them. This indicator replaces the percentage of topic frequency with a ranking system and thus encompasses McCombs's concept of agenda (Roberts and McCombs, 1994). 
Analysis of the media studied reveals the common practice of discussing public events as they occur. Therefore, main topics tend to be addressed concurrently in more than one media. This is clearly visible in the percentages for "government and public institutions," which almost always ranks at the top of the three national newspapers, illustrating their "watchdog" function. The space dedicated by the editorials of Santiago-based newspapers to "government and public institutions" increased over the three years studied, from an average of $14.5 \%$ in 2005 to $17 \%$ in 2009 and to $22.3 \%$ in 2011 .

The trend is not replicated to a similar degree in regional media during 2005 and 2009. The year 2011, however, shows a marked increase in the number of editorials on "government and public institutions" over previous years, for a total of $20.6 \%$ of all editorials published by El Sur de Concepción.

Examination of media homogeneity in 2005 (see Table 5) illustrates the strong tendency towards uniformity between the agendas of El Mercurio and La Tercera (rho 0.88). This high degree of correlation is not surprising, nor is the thematic range. As noted, Spearman's Rho is not based on the percentages obtained by the 14 items analyzed, but on their ranking in order of importance. As indicated previously, La Tercera is more topic-concentrated in its editorials, while El Mercurio has more thematic diversity.

While the level of correlation between these two Santiago newspapers and La Segunda (the third Santiago paper) is lower, it is still significant. This supports our hypothesis of a significant and sustained overlap in the topics covered in the editorials of these papers during 2005.

Regional newspapers tend to have different agendas than those of their counterparts in the capital. This is apparent in the negative (although not statistically significant) correlations of La Discusión de Chillán. In the case of El Sur de Concepción, this is only partially true, as it demonstrates a high degree of correlation with the editorial agenda of La Segunda. 


\section{Table 5: Inter-media thematic homogeneity, 2005}

\begin{tabular}{|c|c|c|c|c|c|}
\hline $\begin{array}{c}\text { Spearman's } \\
\text { rho }\end{array}$ & 2005 & La Tercera & La Segunda & La Discusión & El Sur \\
\hline \multirow{2}{*}{ El Mercurio } & \multirow{2}{*}{$\begin{array}{l}\text { correlation } \\
\text { Sig. (bilateral) }\end{array}$} & $0,88^{* *}$ & $0,58^{*}$ & $-0,17$ & 0,37 \\
\hline & & 0,00 & 0,03 & 0,57 & 0,19 \\
\hline \multirow[t]{2}{*}{ La Tercera } & \multirow{2}{*}{$\begin{array}{l}\text { correlation } \\
\text { Sig. (bilateral) }\end{array}$} & & $0,60^{*}$ & $-0,17$ & 0,38 \\
\hline & & & 0,02 & 0,56 & 0,18 \\
\hline \multirow[t]{2}{*}{ La Segunda } & \multirow{2}{*}{\begin{tabular}{|l} 
correlation \\
Sig. (bilateral) \\
\end{tabular}} & & & $-0,29$ & $0,83^{* *}$ \\
\hline & & & & 0,32 & 0,00 \\
\hline La Discusión & $\begin{array}{l}\text { correlation } \\
\text { Sig. (bilateral) }\end{array}$ & & & & $\begin{array}{l}0,08 \\
0,79\end{array}$ \\
\hline
\end{tabular}

In 2009 (see Table 6), the homogeneity of the topics addressed in the editorials of Santiago newspapers increased between El Mercurio and La Tercera, and with La Segunda. La Tercera focused its editorials on "government and public institutions." La Segunda devoted as much space as El Mercurio to these topics, but focused its editorial opinions on "politicians and political parties," its signature topic, and -- 2009 being an election year -- "elections, campaigns and election processes." The regional newspapers tended to increase the thematic diversity of their editorials. El Sur de Concepción distanced itself from the agenda of the Santiago-based media (including La Segunda), increasingly resembling La Discusión de Chillán.

\section{Table 6: Inter-media thematic homogeneity, 2009}

\begin{tabular}{|c|c|c|c|c|c|}
\hline $\begin{array}{c}\text { Spearman's } \\
\text { rho }\end{array}$ & 2009 & La Tercera & La Segunda & La Discusión & El Sur \\
\hline \multirow{2}{*}{ El Mercurio } & \multirow{2}{*}{$\begin{array}{l}\text { correlation } \\
\text { Sig. (bilateral) }\end{array}$} & $0,90^{* *}$ & $0,70^{* *}$ & $-0,22$ & 0,25 \\
\hline & & 0,00 & 0,00 & 0,44 & 0,39 \\
\hline \multirow{2}{*}{ La Tercera } & \multirow{2}{*}{$\begin{array}{l}\text { correlation } \\
\text { Sig. (bilateral) }\end{array}$} & & $0,77^{* *}$ & $-0,24$ & 0,21 \\
\hline & & & 0,00 & 0,41 & 0,48 \\
\hline \multirow{2}{*}{ La Segunda } & \multirow{2}{*}{\begin{tabular}{|l} 
correlation \\
Sig. (bilateral) \\
\end{tabular}} & & & $-0,43$ & $-0,30$ \\
\hline & & & & 0,13 & 0,30 \\
\hline \multirow{2}{*}{ La Discusión } & \multirow{2}{*}{$\begin{array}{l}\text { correlation } \\
\text { Sig. (bilateral) }\end{array}$} & & & & $0,54^{*}$ \\
\hline & & & & & 0,04 \\
\hline
\end{tabular}

92 The Ethical Demand for Editorial Diversity in a Context of Concentrated... - Maria Elena Gronemeyer y otro. 
In 2011 (see Table 7), a non-election year, the thematic homogeneity of editorials in Santiago newspapers resembled that of 2005. El Mercurio and La Tercera showed a high correlation between one another, but less than La Segunda. La Discusión de Chillán kept the originality of its agenda (although this time the sign is not minus, or negative, in relation to El Mercurio and La Tercera). El Sur de Concepción accentuated its tendency to employ an agenda similar to that of La Discusión de Chillán. In this case, however (and unlike 2005), it showed greater similarity to El Mercurio than La Segunda. One incidental aspect of the similarities of editorial topics between El Sur de Concepción and La Segunda in 2005, and then again with El Mercurio in 2011, is the fact that Cristián Zegers was the director of La Segun$d a$ in 2005 and of El Mercurio in 2011. This could have had implications for this study if the changes in El Sur de Concepción editorial coverage had occurred after the paper's acquisition by El Mercurio SAP in 2010. Yet, in 2005, when its editorial content showed greater similarity to La Segunda, the paper was still owned independently.

\section{Table 7: Inter-media thematic homogeneity, 2011}

\begin{tabular}{|c|c|c|c|c|c|}
\hline $\begin{array}{c}\text { Spearman's } \\
\text { rho }\end{array}$ & & La Tercera & La Segunda & La Discusión & El Sur \\
\hline \multirow{2}{*}{ El Mercurio } & \multirow{2}{*}{$\begin{array}{l}\text { correlation } \\
\text { Sig. (bilateral) }\end{array}$} & $0,82^{* *}$ & $0,59 *$ & 0,25 & $0,61^{*}$ \\
\hline & & 0,00 & 0,03 & 0,39 & 0,02 \\
\hline La Tercera & $\begin{array}{l}\text { correlation } \\
\text { Sig. (bilateral) }\end{array}$ & & $\begin{array}{c}0,57^{*} \\
0,03\end{array}$ & $\begin{array}{l}0,24 \\
0,41\end{array}$ & $\begin{array}{l}0,50 \\
0,07\end{array}$ \\
\hline \multirow{2}{*}{ La Segunda } & correlation & & & $-0,15$ & 0,12 \\
\hline & Sig. (bilateral) & & & 0,62 & 0,67 \\
\hline \multirow[t]{2}{*}{ La Discusión } & \multirow{2}{*}{$\begin{array}{l}\text { correlation } \\
\text { Sig. (bilateral) }\end{array}$} & & & & $0,70^{* *}$ \\
\hline & & & & & 0,01 \\
\hline
\end{tabular}

In summary, this study supports the thesis that the three Santiagobased newspapers show a high degree of homogeneity in the themes of their editorials, at least in terms of their priority topics. In contrast, the regional papers studied show a greater tendency to cover a different agenda, although this occurs only partially in El Sur de Concepción. While the similarity between El Sur de Concepción and La Discusión de Chillán is to be ex- 
pected (they are located in the same administrative district), the coincidence of the priorities of El Sur de Concepción first with La Segunda and then with El Mercurio is notable, and does not support the hypothesis of the impact of change in media ownership on the editorial agenda.

\section{Discussion and conclusions}

Our analysis of 2,343 editorials published in five major Chilean newspapers was the basis for analyzing thematic homogeneity within and among the topics addressed by these media. This phenomenon merits attention, because of the continuing criticism leveled at the press concerning the possible loss of pluralism due to the concentration of media ownership, as discussed above. There is consensus that journalism's ethical duty is to provide citizens with information, reflection and interpretation of a multiplicity of socially relevant topics to allow people's adequate participation in public deliberation on matters affecting the individual and the community. This is an essential requirement of the social contract that guides the information activity of the media, and is also a means to consolidate democracy (Sjøvaag, 2010).

On balance, there is a tendency towards thematic homogeneity and similar media editorial agendas in the Chilean press. This coincides with the position of academics and critics discussed earlier, who perceive the contents of the newspapers of this country as homogeneous and who say they would poorly reflect the reality of its citizens from a variety of perspectives.

As regards intra-media topic homogeneity, this study demonstrates differences among the newspapers reviewed. El Mercurio, the national paper of record owned by El Mercurio SAP, included an increasing variety of topics in its editorials over the period studied. La Tercera, owned by Copesa SA, increased the number of editorials per edition over the period, but addressed fewer topics. La Segunda, the evening paper also owned by El Mercurio SAP, showed the highest thematic homogeneity, specializing in politics and politicians. The greatest variety of editorial topics was found in La Discusión de Chillán and El Sur de Concepción, the two regional newspapers analyzed. 
As regards inter-media thematic homogeneity, this study confirms the Santiago-based newspapers El Mercurio, La Tercera and La Segunda incline towards homogeneity when assigning priority to the topics they choose to editorialize upon. El Mercurio and La Tercera tend to have very similar agendas. The regional newspapers El Sur de Concepción and La Discusión de Chillán present a different agenda, albeit partially.

As regards the hypothesis that concentration of media ownership always generates thematic homogeneity, this study suggests that a greater level of homogeneity may be attributable to geographic location than to ownership. The greatest degree of homogeneity found in this study occurred between different media enterprises (El Mercurio SAP and Copesa SA). However, the findings do confirm the thesis of the influence of the duopoly structure in the Chilean press (where two media enterprises dominate the newspaper market) in setting the editorial agenda.

Regarding intra-media thematic diversity, ownership appears not to be an influencing factor, as El Mercurio and La Segunda exhibit different behavior (the former showing the greatest diversity and the latter the least), despite being owned by the same company.

In conclusion, the research conducted to date confirms the existence of significant thematic overlap in the editorials of Chilean mainstream newspapers. However, it is also necessary to reiterate that, according to the findings of this study, homogeneity in the editorial topics is not due to the concentration of newspaper ownership, or at least it is not the only reason. This requires expanding the hypotheses on the causes of the homogeneity in the Chilean media and opening it up to consider there may be sociological, cultural and historical reasons for this society, as a whole, to traditionally tend to be homogeneous, beyond its media.

At any rate, this trend poses a professional and ethical challenge to national newspapers with regard to their role as providers of diverse contents to satisfy audience needs. In recent years, Chilean society has, in fact, become more diverse due to immigration from many countries, but mainly 
from neighboring nations such as Peru and Bolivia, and for the simple reason that we now live in a globalized world.

Given this context, it also becomes an ethical duty of the media to contribute to integration and to value diversity. To do so, the variety of the topics addressed need to be enlarged, and the editorials have to contextualize and discuss reflexively these new dimensions of reality. If we said that newspapers, through their editorials, contribute to the public discourse on topics of social importance, and society is showing significant changes, it also is an ethical responsibility of the media to make those changes visible and understandable. And, it should soon become evident through a significantly greater diversity of topics covered in their editorials that newspapers are willing and able to contribute to the inclusiveness of all groups who currently make up Chilean society.

\section{References}

Apreza, S. (2005). Concentración de medios de comunicación versus pluralismo informativo externo. Spain: Universidad de Salamanca.

Bandura, A. (1986). Social Foundations of Thought and Action: A Social Cognitive Theory. Englewood Cliffs, NJ. Prentice Hall.

Blanks, E. (2008). "Black Eye: The Ethics of CBS News and the National Guard Documents." Journal of Mass Media Ethics, 23 (2), 90-109.

Carpentier, N. (2007) . "Journalism, Media and Democracy." In Cammaerts, B. and Carpentier, N. (eds). Reclaiming the Media: Communication Rights and Democratic Media Roles, European communication research and education association series 3, (pp. 151-156). Bristol, UK: Intellect.

Cortina, A. (2004) “ “Democracia deliberativa”. In El País, column (date 0824-2004), Spain. Retrieved March 30, 2012, from: http://elpais. com/diario/2004/08/24/opinion/1093298406_850215.html

96 The Ethical Demand for Editorial Diversity in a Context of Concentrated... - Maria Elena Gronemeyer y otro. 
Corrales, O. and Sandoval, J. (2004). Concentración del mercado de los medios, pluralismo y libertad de expresión. Working paper, Centro de Estudios de la Comunicación, CECOM 1, Universidad de Chile, Santiago.

Del Valle, C. (2004). "Metainvestigación de la comunicación en Chile (1970-2003). Reflexiones y críticas desde la economía política de la comunicación." Revista Latinoamericana de Ciencias de la Comunicación, 1, 126-133.

Dermota, K. (2002). Chile Inédito: El periodismo bajo democracia. Santiago, Chile: Ediciones B.

Eilders, Ch. (2000). "Media as political actors? Issue focusing and selective emphasis in the German quality press." German Politics, 9 (3), 181-206.

Ettema, J.S. (2007). “Journalism as Reason-giving: Deliberative democracy, Institutional Accountability, and the News Media's Mission." Political Communication, 24, 143-160.

Filippi, E. (1997). Fundamentos del Periodismo. Ciudad de México: Editorial Trillas.

Freedman, D. (2005). "Promoting Diversity and Pluralism in Contemporary Communication Policies in the United States and the United Kingdom." The International Journal on Media Management, 7 $(1,2), 16-23$.

Fuenzalida, V. (2005). Expectativas educativas de las audiencias televisivas. Bogotá; Santiago de Chile: Grupo Editorial Norma.

George, E. (2007). "Concentration in the communication industries. Reflections from Quebec.” Zer, 22, 235-250.

George, L. (2007). “What's Fit to Print: The Effect of Ownership Concentration on Product Variety in Daily Newspaper Markets.” Information, Economics and Policy 19 (3, 4), 285-303. 
Glasser, T. (2005). "Structure and Control of the American Press." In G. Overholser and K. Hall Jamieson (eds). The Press (pp. 333-336), New York: Oxford University Press.

Glasser, T. and Awad, I. (2010). "News and Inclusion: Journalism and the Politics of Diversity." A Symposium at Stanford University, Thursday, March 4. Retrieved May 26, 2012 from: http://comm.stanford.edu/newsandinclusion

González, C. (2005). La construcción del destinatario discursivo en los editoriales de prensa. Ph.D. thesis, School of Philosophy and Education, Universidad de Valparaíso and Université Paris 13, pp.525.

González, G. (2008). “Medios de comunicación en Chile bajo el signo de la concentración.” The Media in Latin America. McGraw-Hill Education.

González, S. (1991). Géneros Periodísticos I, Periodismo de Opinión y Discurso. Mexico: Editorial Trillas.

Grittmann, E. (2009). "Vereinheitlichung statt Vielfalt? Eine Inhaltsanalyse zur Qualität der Tageszeitungen in Mecklenburg-Vorpommern und Schleswig-Holstein." Report of work in progress presented during May in Schwerin, Germany. Retrieved March 30, 2012, from: http://www.djvmv.de/download/Vereinheitlichung_statt_Vielfalt_Projektbericht.pdf

Gutmann, A. and Thompson, D. (2004). Why deliberative democracy? Princeton, NJ: Princeton University Press.

Ho, D. and Quinn, K. (2009). "Viewpoint Diversity and Media Consolidation: An Empirical Study.” Stanford Law Review, 61(4), 781-868.

Horwitz, R.B. (2005). “On Media Concentration and the Diversity Question.” The Information Society: An International Journal, 21 (3), 181 - 204.

Krohne, W. (2002). La libertad de expresión en Chile bajo la atenta mirada de la crítica: balance de 12 años de democracia 1990-2002. Santiago: Fundación Konrad Adenauer. 
Lasch, C. (1995). "Journalism, Publicity, and the Lost Art of Argument." Media Studies Journal. 9 (1), 81-91.

Llorens, C. (2003). “Concentración de medios." Quaderns del CAC 16, 43-52.

McCombs, M. (2005). "A Look at Agenda-setting: Past, Present and Future." Journalism Studies 6 (4), 543-557.

McQuail, D. (1998). La acción de los medios. Los medios de comunicación y el interés público. Buenos Aires: Amorrortu.

Mönckeberg, M.O. (2009). Los magnates de la prensa: concentración de los medios de comunicación en Chile, Santiago: Debate.

Murciano, M. (2006). "Las políticas de comunicación ante los retos del nuevo milenio: Pluralismo, diversidad cultural, desarrollo económico y tecnológico y bienestar social." Zer, 20, 371-398.

Neuendorf, K. (2002). The Content Analysis Guidebook. Sage, Thousand Oaks.

Porath, W. (2000). "El Rol de los Diarios en la Fijación de la Agenda para Dos Temas Claves en la Campaña Electoral de 1999 en Chile.” Paper presented at the WAPOR Conference (World Association for $\mathrm{Pu}$ blic Opinion Research): Democracia y Milenio, Pamplona, Spain.

Porath, W. (2000b). La agenda de la prensa nacional durante la campaña presidencial 1999. Working paper, Facultad de Comunicaciones UC, Santiago, Chile.

Porath, W. (2007). "Los temas de la discusión pública en las elecciones presidenciales chilenas 2005: Relaciones entre las agendas de los medios y las agendas mediatizadas de los candidatos y del gobierno." América Latina Hoy, 46, 41-73.

Porath, W. (2007b). "Medios de Comunicación y Campaña Electoral 2005." In Carlos Huneeus, Fabiola Berríos and Ricardo Gamboa (eds). Las elecciones chilenas de 2005. Santiago: Catalonia (pp.197-222). 
Portales, D. (1999). "La Concentración de los Medios y la Libertad de Expresión.” In Los usos de la Libertad de Expresión. Working paper, Escuela de Periodismo, Universidad de Chile, Santiago.

Rennhoff, A. and Wilbur, K. (2011). "Local Media Ownership and Viewpoint Diversity in Local Television News” (August 26). Retrieved May 26, 2012, from: http://ssrn.com/abstract $=1917756$ or http://dx.doi.org/10.2139/ssrn.1917756

Roberts, M. and McCombs, M. (1994). "Agenda setting and political advertising: Origins of the news agenda." Political Communication, 11(3), 249-262.

Sánchez-Tabernero, A. (2006). "Gestión de medios: Periodistas en la cuerda floja.” Cuadernos de Información, 19, 56-61.

Santander, P. (2007). "Medios en Chile 2002-2005: Entre la lucha por el poder y la sumisión al espectáculo.” In P. Santander (ed). Los Medios en Chile: Voces y Contextos, Valparaíso: Ediciones Universitarias de Valparaíso (pp.11-38).

Schudson, M. (1995). The power of news. Cambridge, MA: Harvard University Press.

Sjøvaag, H. (2010). “The reciprocity of journalism's social contract.” Journalism Studies, 11: 6, 874-888.

Soto, A. (2003). El Mercurio y la Difusión del pensamiento Político-Económico Liberal, 1955-1970. Santiago: Ediciones Centro de Estudios Bicentenario.

Stein, J.L. (2005). Democracia y medios de comunicación. México, Universidad Nacional Autónoma de México.

Stevenson, N. (2002). Understanding Media Cultures. London: SAGE Publications. 
Sullivan, M. (2005). “Media Bias Is Real.” UCLA Newsroom. Retrieved May 21, 2012, from: http://newsroom.ucla.edu/portal/ucla/Media-Bias-Is-Real-Finds-UCLA-6664.aspx? RelNum=6664

Sunkel, G. (1986). "El Mercurio como medio de educación político-ideológica (1969-1979).” In Reyes Matta, F., C. Ruiz y G. Sunkel (eds), Investigación sobre la prensa en Chile (1974-1984). Santiago: CERCILET (pp. 99-111).

Sunkel, G and Geoffroy, E. (2001). Concentración económica de los medios de comunicación. Santiago: LOM Ediciones.

Van Cuilenburg, J. (2002). The media diversity concept and European perspectives. Media Economy, Content and Diversity Seminar, Finnish Academy of Sciences, Helsinki. Retrieved March 30, 2012, http:/ / www.cvdm.nl/dsresource?objectid=6838andtype $=$ org

Valenzuela, S. and Arriagada, A. (2009). "Competencia por la uniformidad en noticiarios y diarios chilenos 2000-2005." Cuadernos de Información, 24 (January-June), 41-52.

Viera, A.J. and Garrett J.M. (2005). "Understanding Interobserver Agreement: The Kappa Statistic.” Family Medicine 37 (5), 360-363.

Villamil, J. (2009). "Concentración mediática y lavado de cerebros en América Latina." Observatorio de Medios Fucatel (electronic journal, July). Retrieved May 27, 2010, from: http://www.observatoriofucatel.cl/concentracion-mediatica-y-lavado-de-cerebros-en-america-latina/

Woods, J. (2007). "Democracy and the press: A comparative analysis of pluralism in the international print media." The Social Science Journal, 44 (2), 213-230. 